\title{
NOTES ON A PEREGRINE FALCON AND FRANKLIN'S GULL ENCOUNTER
}

\author{
by B. J. Rose, Bismarck, North Dakota
}

On September 16, 1965, I witnessed a most spectacular display of aerial acrobatics. The two participants in the drama were an immature Peregrine Falcon (Falco peregrinus) and an immature Franklin's Gull (Larus pipixcan). I was returning to North Dakota from Regina on the above date and noticed what first appeared to be two falcons playing just south of the Trans-Canada Highway. I stopped the car and observed the falcon attempting to take the gull. The chase paralleled and several times crossed Highway 6.

The falcon stooped many times at the gull, but through skillful dodging the latter would escape. After a stoop, the falcon tried three different tactics. The first was to gain altitude immediately and prepare for another stoop when the opportunity presented itself. The second was to pull out of the stoop and give a straight-a-way chase. However, this manoeuvre was unsuccessful since it appeared that the gull could maintain a slight lead during such chases. The third tactic was to pull out of the stoop and zoom up and over without righting itself (loop), executing a complete circle, and returning to the prey at a terrific rate of speed. When the later tactic was employed, falcon and gull came together head-on in about half the instances, the gull having reversed its direction after the first stoop. The gull's tactics were also of three types. The first was to fall off to right or left. This was employed during the stoop or on a straight-a-way chase. The second was to reverse direction (chandelle), usually after a missed stoop. The third tactic was to follow the falcon upwards after a missed stoop. On several occasions the gull was at a greater altitude than the falcon after the manoeuvre was completed.

In order to follow the chase it was necessary for me to drive ahead of the birds and wait for them. The general route of the chase was south. Several observations were of interest. At one point the gull flew back and forth over a small pothole upon which several ducks were swimming. The falcon paid no heed to these prey species, but continued to pursue the gull. The ducks did not flush from the water although the falcon came within a few feet of them when stooping at the gull. The latter did not land. On another occasion a flock of approximately 75 gulls were passed in the chase. The falcon did not alter its course towards the flock, but continued after its prey. At another point, I was ahead of the pair when the gull dived and passed down the highway about 10 feet from me. The falcon maintained pursuit, paying no heed to my close proximity. Two additional passes were made by the gull near the car, but the falcon continued the pursuit. The end of the struggle came about one-quarter mile north of Rowatt. The falcon made a stoop, a puff of feathers appeared from the gull's back and it fell to the ground. The falcon made one pass over the fallen prey and returned to deliver the "coup de grace."

I don't know where this chase originated, but believe it possibly started near the Wascana Waterfowl Park. The portion of the pursuit I witnessed covered approximately four miles and lasted for about 20 minutes. It appeared that the gull was tiring towards the end of the struggle and perhaps the straight-a-way pursuits and constant harassment did tire it. I was surprised that the falcon continued the chase after so many unsuccessful attempts to take the gull. Perhaps others have seen similar chases, but this life and death struggle was the most spectacular I have ever witnessed. 